\title{
Pengaruh Orientasi Kewirausahaan Dan Inovasi Produk Terhadap Kinerja Usaha Kecil Menengah (UKM) (Studi Kasus Pada UKM Tenun Di Kecamatan Pringgasela Kabupaten Lombok Timur)
}

\author{
Nova Hari Santhi ${ }^{1}$, Yuniar Affandi ${ }^{2}$ \\ ${ }^{1}$ Prodi Ilmu Administrasi Negara STIA Muhammadiyah Selong \\ Email: novaharisanthi@gmail.com
}

Received: 10 Maret, 2020; Accepted: 17 Mei, 2020; Published: 27 Juni, 2020

\begin{abstract}
Abstrak
Tujuan utama penelitian ini adalah (1) Menganalisis Pengaruh Orientasi Kewirausahaan dan Inovasi Produk terhadap Kinerja UKM Secara tersendiri (Parsial), (2) Menganalisis Pengaruh Orientasi Kewirausahaan dan Inovasi Produk terhadap Kinerja UKM Secara bersama-sama (simultan) Penelitian ini merupakan jenis penelitian kausalitas yaitu penelitin sebab akibat. Populasi dalam penelitian ini adalah seluruh UKM Tenun yang berada di Kecamatan Pringgasela yang berjumlah 110 UKM. Sampel dalam penelitian ini menggunakan sampel jenuh yaitu seluruh populasi dijadikan sampel. Pengumpulan data menggunakan metode angket atau kuesioner. Metode angket atau kuesioner dialakukan untuk mendapatan tanggapan responden mengenai Orientasi Kewirausahaan dan Inovasi Produk dan Kinerja UKM Tenun. Analisis data yang digunakan untuk menguji hipotesis dalam penelitian ini adalah menggunakan analisis Regresi Linier Berganda yang terdapat dalam program SPSS v. 19.

Hasil penelitian secara parsial (sendiri) menunjukan bahwa variabel Orientasi Kewirausahaan, yaitu t-hitung > t-tabel atau 5,627 > 1,660 maka Ho ditolak dan hipotesis penelitian diterima, artinya Orientasi Kewirausahaan mempunyai pengaruh yang positif dan signifikan terhadap kinerja keuangan pada UKM Tenun Di Desa Pringgasela. Variabel Inovasi Produk, yaitu t-hitung > ttabel atau 5,359 > 1,660 maka Ho ditolak dan hipotesis penelitian diterima, artinya Inovasi Produk mempunyai pengaruh yang positif dan signifikan terhadap Kinerja keuangan pada UKM Tenun Di Desa Pringgasela. Hasil Pengujian hipotesis secara simultan (bersama-sama), dari hasil pengolahan data diketahui bahwa $\mathrm{F}$ hitung sebesar 39,030 dan F-tabel pada derajat bebas regresi 2 dan derajat bebas residual 109 serta $\alpha 0,05$ adalah 3,09. F hitung $>\mathrm{F}$ tabel $(39,030>3,09)$, maka Ho ditolak, artinya ada pengaruh yang signifikan variabel Orientasi Kewirausahaan dan Inovasi Produk secara bersama-sama terhadap terhadap Kinerja Keuangan UKM Tenun Di Desa Pringgasela.
\end{abstract}

Kata Kunci : Orientasi Kewirausahaan; Inovasi Produk; dan Kinerja UKM. 


\begin{abstract}
The main objectives of this study are (1) Analyzing the Effect of Entrepreneurship Orientation and Product Innovation on SME Performance Individually (Partial), (2) Analyzing the Effect of Entrepreneurship Orientation and Product Innovation on UKM Performance Together (simultaneous). This research is a type of causality research, which is a causal researcher. The population in this study were all Weaving UKM located in Pringgasela District, which amounted to $110 \mathrm{UKM}$. The sample in this study used saturated samples, that is, the entire population was sampled. Data collection using questionnaire or questionnaire method. Questionnaire methods or questionnaires were conducted to obtain respondents' responses regarding Entrepreneurship Orientation and Product Innovation and Weaving SME Performance. Data analysis used to test the hypothesis in this study is to use the analysis of Multiple Linear Regression contained in the SPSS program v. 19.

The results of the research partially (self) show that the Entrepreneurship Orientation variable, namely $\mathrm{t}$-count $>\mathrm{t}$-table or 5,627>1,660, then Ho is rejected and the research hypothesis is accepted, meaning Entrepreneurship Orientation has a positive and significant influence on financial performance in UKM Weaving in the Village Pringgasela. Product Innovation Variables, namely tcount> t-table or 5.359>1.660 then Ho is rejected and the research hypothesis is accepted, meaning that Product Innovation has a positive and significant influence on financial performance in UKM Weaving in Pringgasela Village. Hypothesis testing results simultaneously (together), from the results of data processing, it is known that $\mathrm{F}$ count is 39.030 and $\mathrm{F}$-table in regression 2 free degrees and residual free degrees 109 and $\alpha 0.05$ are 3.09 . F count $>F$ table $(39,030>3,09)$, then Ho is rejected, meaning that there is a significant influence variable Entrepreneurship Orientation and Product Innovation together towards the Financial Performance of Weaving SMEs in Pringgasela Village.
\end{abstract}

Keywords: Entrepreneurship Orientation; Product Innovation; UKM Performance.

\title{
PENDAHULUAN
}

Usaha Kecil dan Menengah (UKM) sebagai salah satu komponen pembangunan bidang ekonomi memiliki peran yang sangat strategis dalam perekonomian suatu negara terutama di negara berkembang, karena mampu mendukung terwujudnya peningkatan pendapatan masyarakat, antara lain dengan cara memeratakan pembangunan, memperluas lapangan kerja dan kesempatan berusaha serta melestarikan dan mengembangkan karya kerajinan seni budaya tradisional dan meningkatkan penghasilan/devisa (Murni, 2015). Terlebih lagi di era globalisasi dan perdagangan bebas, UKM seharusnya memiliki peran baru yang lebih penting lagi, yaitu sebagai salah satu faktor pendorong perkembangan dan pertumbuhan ekspor non migas dan sebagai industri pendukung yang memberikan supply kepada industri besar, seperti di Taiwan, Korea selatan, China, Thailand. Oleh karena itu 
UKM harus dapat bersaing dengan produk-produk impor sejenis di pasar domestik maupun pasar global (Hadad, et a.,2004).

Pengembangan UMKM semakin gencar dilakukan pemerintah dan pihak lainnya untuk meningkatkan kinerja sektor ini. Upaya mencapai pengembangan UMKM ini salah satunya dilakukan melalui pengembangan UMKM yang dalam pelaksanaan mengacu pada ASEAN Policy Blue Print for SME Development (APBSD) 2004-2014. Dalam APBSD, pengembangan UMKM dilaksanakan melalui lima program yaitu program pengembangan kewirausahaan, peningkatan kemampuan pemasaran, akses kepada keuangan, akses kepada teknologi dan kebijakan yang kondusif. Untuk dapat meningkatkan usaha dan mampu bersaing menghadapi tatanan global, Usaha Kecil dan Menengah perlu memiliki Orientasi wirausaha yang mendorong semangat inovasi dan kemampuan mengambil resiko yang menunjang keberhasilan usaha. Orientasi wirausaha mencerminkan karakteristik organisasi yang berhubungan dengan perilaku berwirausaha antara lain tingkat pengambilan resiko, inovasi, dan perilaku proaktif dari pelaku bisnis.

Orientasi wirausaha mengacu pada orientasi strategik sebuah bisnis namun juga mencakup aspekaspek gaya, metode, dan praktik pengambilan keputusan wirausaha yang spesifik (Lumpkin dan Dess, 1996). UKM yang memiliki orientasi wirausaha tinggi akan cenderung melakukan tindakan-tindakan yang didasarkan pada keputusan inovatif, berani mengambil resiko bisnis dan cenderung melakukan tindakan yang proaktif dalam mengantisipasi persaingan usaha dan memanfaatkan peluang. Hal ini akan mendorong kinerja yang semakin baik. Orientasi kewirausahaan tidak hanya memiliki hubungan dengan peningkatan kinerja atau keberhasilan perusahaan, akan tetapi juga memiliki hubungan dengan kemampuan manajemen dan strategi bisnis. Pemilik UKM yang mempunyai jiwa entrepreneur serta didukung dengan kemampuan manajemen, sangat penting dan diperlukan untuk mengkoordinasikan sumber daya perusahaan agar dapat diperoleh hasil yang efektif dan efisien (Tidd, 1998).

Selain orientasi kewirausahaan, inovasi produk tidak kalah penting. Produk yang ditampilkan oleh pemilik usaha harus memiliki inovasi. Keunikan produk 
sebagai hasil inovasi secara temporer akan membawa persaingan yang lebih besar (McDaniel, 2002:105) bahkan inovasi yang diciptakan oleh perusahaan menjadi kunci dari keunggulan bersaing yang menentukan kesuksesan ekonomi dari suatu organisasi (Urbancova, 2013:94). Dengan memiliki keunggulan bersaing suatu usaha akan mampu bertahan sehingga dalam pengukuran keberhasilannya, daya saing usaha yang ada mendukung kinerja usaha termasuk kinerja pemasaran dari suatu usaha (Hasan, 2013:291).

Inovasi merupakan pengenalan dan aplikasi yang disengaja dalam pekerjaan, tim kerja atau organisasi mengenai ide, proses, produk atau prosedur yang baru dalam pekerjaan, tim kerja atau organisasi, yang dirancang untuk menguntungkan pekerjaan, tim kerja atau organisasi tersebut (West, 2000:18 dalam Chyntia dan Hendra, 2014:1217). Inovasi merupakan proses no-linear dari dua komponen meliputi implementasi kreativitas dan inovasi. Pada awal proses, kreativitas mendominasi dan kemudian, akan didominasi oleh proses implementasi inovasi. Inovasi dalam kewirausahaan terbagi atas dua tipe inovasi yang membentuk keuntungan bagi suatu usaha dengan cara yang berbeda yaitu inovasi produk dan inovasi proses (McDaniel,2002:105 dalam Chyntia dan Hendra,2014:1217).

Bervariasinya pengukuran kinerja keuangan UKM yang diawali dengan tingkat pencatatan laporan keuangan, berlaku di semua sektor usaha (Prasetya, 2002:227). Berbagai kelemahan internal yang mempengaruhi kinerja dan keberhasilan atau kegagalan UKM diantaranya adalah ketidakjelasan pengelolaan keuangan untuk menjalankan aktivitas bisnis yang intinya adalah memisahkan keuangan pemilik dengan modal usaha. Masalah keuangan merupakan salah satu masalah vital bagi perusahaan termasuk UKM.Salah satu tujuan utama didirikannya perusahaan adalah untuk memperoleh keuntungan yang maksimal.Berhasil tidaknya perusahaan dalam mencari keuntungan dan mempertahankan perusahaan tergantung pada manajemen keuangan.

Kemampuan perusahaan dalam menghasilkan keuntungan merupakan kunci keberhasilan perusahaan untuk dapat dikatakan mempunyai kinerja perusahaan yang baik, karena keuntungan atau laba merupakan komponen laporan keuangan yang digunakan sebagai alat untuk menilai baik tidaknya kinerja perusahaan. Hal 
ini dapat mempengaruhi keberlangsungan hidup perusahaan atau UKM untuk dapat bekerjasama dengan perusahaan atau UKM yang lain

Salah satu sektor usaha unggulan Lombok Timur adalah sektor usaha Tenun, khususnya tenun Pringgasela yang dikelola oleh UKM. Tenun adalah karya seni budaya bangsa Indonesia yang dikagumi dunia dan patut dilestarikan keberadaannya serta dibudidayakan secara maximal, dan tenun merupakan industri kerajinan yang merupakan usaha turun-temurun dari generasi ke generasi, namun belum sepenuhnya ditangani secara profesional sehingga perkembangannya relatif sangat lamban.

Kabupaten Lombok Timur khususnya Desa Pringgasela yang dikenal sebagai sentra pembuatan Tenun menemukan beberapa kendala yaitu belum sepenuhnya mampu menciptakan inovasi yang modern dan masih menggunakan desain yang lama sehingga belum mampu bersaing dengan tenun dari Bima, para pengrajin tenun sebagian besar juga masih kesulitan untuk menjangkau pasar nasional maupun internasinal karena kurang adanya informasi yang mereka dapatkan sehingga hal ini dapat melemahkan kinerja keuangan UKM. Namun Mereka tetap eksis secara turun-temurun dengan mengandalkan kemampuan sendiri yang kemudian daerah ini dibangun menjadi pusat tenun di Lombok Timur.

Berbagai literatur menggambarkan orientasi kewirausahaan sebagai entrepreneur personality (Littunen, 2000; Lee and Tsang, 2001; Olson, 2000). Di lain pihak Hisrich, Peters and Sheperd (2005) menyatakan bahwa orientasi kewirausahaan sebagai entrepreneurial feelings. Knight (2000) menjelaskan bahwa orientasi kewirausahaan berkaitan dengan pencarian peluang, keberanian mengambil resiko dan keputusan untuk bertindak dari pimpinan organisasi. Orientasi kewirausahan akan menjadi sistem nilai bagi perusahaan dan akan menentukan gerak atau strategi perusahaan. Perusahaan yang memiliki sistem nilai akan terus mencari peluang, untuk mencoba memasuki pasar baru guna mengambil peluang yang ada.

Berdasarkan latar belakang yang ada peneliti dapat menarik benang merah dari permasalahan yang dihadapi oleh UKM sehingga peneliti tertarik untuk melakukan penelitian yang berjudul "Pengaruh Orientasi Kewirausahaan dan 
Inovasi Produk terhadap Kinerja Keuangan UKM Tenun (Studi kasus Pada UKM Tenun Di Pringgasela Kab. Lombok Timur)".

\section{METODE}

Penelitian ini merupakan jenis penelitian kausalitas yaitu penelitin sebab akibat. Populasi dalam penelitian ini adalah seluruh UKM Tenun yang berada di Kecamatan Pringgasela yang berjumlah 110 UKM. Sampel dalam penelitian ini menggunakan sampel jenuh yaitu seluruh populasi dijadikan sampel. Pengumpulan data menggunakan metode angket atau kuesioner. Metode angket atau kuesioner dialakukan untuk mendapatan tanggapan responden mengenai Orientasi Kewirausahaan dan Inovasi Produk dan Kinerja UKM Tenun. Analisis data yang digunakan untuk menguji hipotesis dalam penelitian ini adalah menggunakan analisis Regresi Linier Berganda yang terdapat dalam program SPSS v. 19.

\section{HASIL PENELITIAN DAN PEMBAHASAN}

Analisis Regresi bertujuan untuk menganalisis besarnya pengaruh variabel bebas (independent) terhadap veriabel terikat (dependent). Regresi linier berganda digunakan untuk menguji pengaruh lebih dari satu independet variabel terhadap dependet variabel.

\section{Korelasi Berganda}

Analisis ini digunakan untuk mengetahui hubungan antara dua atau lebih variabel independen $\left(\mathrm{X}_{1}, \mathrm{X}_{2}, \ldots \mathrm{X}_{\mathrm{n}}\right)$ terhadap variabel dependen $(\mathrm{Y})$ secara serentak. Koefisien ini menunjukkan seberapa besar hubungan yang terjadi antara variabel independen $\left(\mathrm{X}_{1}, \mathrm{X}_{2}, \ldots \ldots \mathrm{X}_{\mathrm{n}}\right)$ secara serentak terhadap variabel dependen $(\mathrm{Y})$. nilai $\mathrm{R}$ berkisar antara 0 sampai 1 , nilai semakin mendekati 1 berarti hubungan yang terjadi semakin kuat, sebaliknya nilai semakin mendekati 0 maka hubungan yang terjadi semakin lemah.

Dari hasil analisis regresi, lihat pada output model summary dan disajikan pada tabel 1 sebagai berikut:

Tabel 1

Hasil Analisis Korelasi Berganda

\begin{tabular}{rrr}
\hline \multicolumn{2}{r}{$\mathbf{R}$} & \multicolumn{2}{c}{ R-Square } & Adjusted $\mathbf{R}-$ Square \\
\hline $0,649^{\mathrm{a}}$ & 0,422 & 0,411 \\
\hline
\end{tabular}


Sumber: data dioalah, 2018

Berdasarkan tabel 1 di atas diperoleh angka $\mathrm{R}$ sebesar 0,649. Hal ini menunjukkan bahwa terjadi hubungan yang sangat kuat antara Orientasi Kewirausahaan dan Inovasi Produk Terhadap Kinerja UKM Tenun di Desa Pringgasela.

Berdasarkan tabel 1 di atas diperoleh angka Adjusted R Square sebesar 0,411 atau $(41,1 \%)$. Hal ini menunjukkan bahwa prosentase sumbangan pengaruh variabel independen (Orientasi Kewirausahaan dan Inovasi Produk) terhadap variabel dependen (kinerja UKM) sebesar 41,1\%. Atau variasi variabel independen yang digunakan dalam model (Orientasi Kewirausaan dan Inovasi Produk) mampu menjelaskan sebesar 41,1\% variasi variabel dependen (Kinerja UKM). Sedangkan sisanya sebesar 58,9\% dipengaruhi atau dijelaskan oleh variabel lain yang tidak dimasukkan dalam model penelitian ini.

\section{Uji Hipotesis}

\section{Pengujian Hipotesis secara sendiri (Parsial)}

Uji ini digunakan untuk mengetahui apakah dalam model regresi variabel independen $\left(\mathrm{X}_{1}, \mathrm{X}_{2}, \ldots . . \mathrm{X}_{\mathrm{n}}\right)$ secara parsial berpengaruh signifikan terhadap variabel dependen (Y).

Dari hasil analisis regresi output dapat disajikan pada tabel 2 sebagai berikut:

Tabel 2. Hasil Uji t

\section{Coefficients $^{\mathbf{a}}$}

\begin{tabular}{|ll|r|r|r|r|r|}
\hline \multirow{2}{*}{ Model } & \multicolumn{2}{|c|}{$\begin{array}{c}\text { Unstandardized } \\
\text { Coefficients }\end{array}$} & $\begin{array}{c}\text { Standardized } \\
\text { Coefficients }\end{array}$ & & \\
\cline { 2 - 4 } & \multicolumn{1}{|c|}{$\mathrm{B}$} & Std. Error & \multicolumn{1}{c|}{ Beta } & \multicolumn{1}{c|}{ S Sig. } \\
\hline 1 & (Constant) & 8,744 & 3,935 & & 2,222 & 0,028 \\
& Orientasi_Kewirausahaan & 0,454 & 0,081 & 0,425 & 5,627 & 0,000 \\
& Inovasi & 0,345 & 0,064 & 0,404 & 5,359 & 0,000 \\
\hline
\end{tabular}

Sumber: Data Primer diolah, 2018

Berdasarkan Tabel 2 diatas, maka dapat dibuat model regresi linier berganda dengan persamaan sebagai berikut:

$$
Y=8,744+0,454 X_{1}+0,343 X_{2}+e
$$


Nilai masing-masing koefisien regresi Variabel Independen dari model regresi linier tersebut memberikan gambaran bahwa:

1. Koefisien Regresi Variabel Orientasi Kewirausahaan (X1) sebesar 0,454 menggambarkan bahwa Orientasi Kewirausahaan mempunyai pengaruh positif dan signifikan (nilai sig $0,000<0,05$ ) terhadap kinerja keuangan UKM Tenun di desa Pringgasela, artinya dengan semakin besarnya Orientasi Kewirausahaan maka Kinerja Keuangan UKM akan makin meningkat.

2. Koefisien Regresi Variabel Inovasi Produk (X2) sebesar 0,345 menggambarkan bahwa Inovasi Produk mempunyai pengaruh positif dan signifikan (nilai sig 0,000<0,05) terhadap kinerja keuangan UKM Tenun Di Desa Pringgasela, artinya dengan semakin tingginya Inovasi Produk maka kinerja keuangan UKM Tenun Di Desa Pringgasela semakin meningkat.

Uji hipotesis secara parsial digunakan untuk mengetahui pengaruh dari masing-masing Variabel Independen terhadap Variabel Dependen. Uji ini dilakukan dengan membandingkan nilai t-hitung dengan nilai t-tabel. Nilai t-hitung dari hasil pengolahan data dengan program SPSS dapat dilihat pada Tabel 2 Hasil Uji t.

Hipotesis Statistik yang diajukan untuk Uji t adalah:

$$
\text { Ho: } \begin{array}{lll}
\mathrm{b}_{1}=0 & \text { Ha : } & \mathrm{b}_{1} \neq 0 \\
\mathrm{~b}_{2}=0 & \mathrm{~b}_{2} \neq 0 \\
\mathrm{~b}_{3}=0 & \mathrm{~b}_{3} \neq 0
\end{array}
$$

Untuk memperoleh nilai t-tabel, dapat dilihat pada tabel t, yaitu pada Degrees of Freedom (df) sebesar 108 (df residual pada ANOVA) dan $\alpha=5 \%$ (uji dua arah) maka nilai t-tabel sebesar 1,660.

Dengan membandingkan nilai t-hitung dengan t-tabel maka dapat disimpulkan:

1. Variabel Orientasi Kewirausahaan, yaitu t-hitung > t-tabel atau 5,627 > 1,660 maka Ho ditolak dan hipotesis penelitian diterima, artinya Orientasi Kewirausahaan mempunyai pengaruh yang signifikan terhadap kinerja keuangan pada UKM Tenun Di Desa Pringgasela. 
2. Variabel Inovasi Produk, yaitu t-hitung > t-tabel atau 5,359 > 1,660 maka Ho ditolak dan hipotesis penelitian diterima, artinya Inovasi Produk mempunyai pengaruh yang signifikan terhadap Kinerja keuangan pada UKM Tenun Di Desa Pringgasela.

\section{Pengujian Hipotesis secara bersama-sama (Simultan)}

Uji ini digunakan untuk mengetahui variabel independen (Orientasi Kewirausahaan dan Inovasi Produk) secara bersama-sama berpengaruh secara signifikan terhadap variabel dependen (Kinerja Keuangan UKM). Atau untuk mengetahui apakah model regresi dapat digunakan untuk memprediksi variabel dependen atau tidak. Signifikan berarti hubungan yang terjadi dapat berlaku untuk populasi (dapat digeneralisasikan). Dari hasil output analisis regresi dapat diketahui nilai F seperti pada tabel 3 berikut ini:

Tabel 3

Hasil ANOVA - Uji F

ANOVA

\begin{tabular}{|rl|r|r|r|r|r|}
\hline \multicolumn{2}{|l|}{ Model } & \multicolumn{1}{|c|}{$\begin{array}{c}\text { Sum of } \\
\text { Squares }\end{array}$} & \multicolumn{1}{c|}{ df } & \multicolumn{1}{c|}{$\begin{array}{c}\text { Mean } \\
\text { Square }\end{array}$} & F & \multicolumn{1}{c|}{ Sig. } \\
\hline 1 & Regression & 573,236 & 2 & 286,618 & 39,030 &, $000^{\mathrm{a}}$ \\
& Residual & 785,755 & 107 & 7,344 & & \\
& Total & 1358,991 & 109 & & & \\
\hline
\end{tabular}

Sumber: Data Primer diolah, 2018

Pengujian hipotesis dilakukan dengan membandingkan nilai $\mathrm{F}$ hitung dengan F-tabel. Dari hasil pengolahan data diketahui bahwa F hitung sebesar 39,030 dan F-tabel pada derajat bebas regresi 2 dan derajat bebas residual 109 serta $\alpha 0,05$ adalah 3,09. $\mathrm{F}$ hitung $>\mathrm{F}$ tabel $(39,030>3,09)$, maka Ho ditolak, artinya ada pengaruh yang signifikan variabel Orientasi Kewirausahaan dan Inovasi Produk secara bersama-sama terhadap terhadap Kinerja Keuangan UKM Tenun Di Desa Pringgasela. Jadi dapat disimpulkan bahwa Orientasi Kewirausahaan dan Inovasi Produk secara bersama-sama terhadap Kinerja Keuangan UKM Tenun Di Desa Pringgasela. Selain membandingkan nilai $\mathrm{F}$ hitung $\mathrm{n} F$ tabel, dengan 
membandingkan nilai Sig dengan nilai $\alpha$ yaitu Sig $<\alpha 5 \%(0,000<0,05)$ maka Ho ditolak dan Ha diterima, artinya Orientasi Kewirusahaa dan Inovasi Produk secara bersama-sama (simultan) mempunyai pengaruh yang signifikan terhadap kinerja keuangan UKM Tenun di Desa Pringgasela.

\section{Pembahasan}

Berdasarkan hasil analisis standardize coefficient regresi pada Tabel 4, dapat diketahui urutan variabel mana yang memiliki pengaruh paling dominan terhadap kinerja keuangan UKM di Desa Pringgasela.

Tabel 4

Nilai Standardize Coefficient Hasil Analisis Regresi

\begin{tabular}{|l|c|}
\hline \multicolumn{1}{|c|}{ Model } & Std. Coeff. \\
\hline Orientasi Kewirausahaan (X1) & 0,454 \\
\hline Inovasi Produk (X2) & 0,345 \\
\hline
\end{tabular}

Sumber: Data Primer diolah, 2018

Tabel 4 menunjukkan bahwa variabel Orientasi Kewirausahaan (X1) adalah variabel yang paling kuat sebagai pengukur kinerja keuangan UKM di Desa Pringgasela. Orientasi kewirausahaan dangat dibutuhkan oleh para pengrajin tenun karena orientasi kewirausahaan ini nantinya mampu mendorong semangat dan antusias para pengrajin tenun untuk dapat mengembangkan usaha yang mereka jalankan. Orientasi kewirausahaan faktor utama yang harus ada di dalam diri para pelaku usaha karena orientasi kewirausahaan berkaitan dengan pencari peluang, keberanian mengambil resiko, dan keputusan untuk bertindak.

Telah dilakukan analisis data dan pengujian terhadap 2 hipotesis penelitian sesuai modul-modul teoritis yang telah diuraikan pada bab II. Hasil yang diperoleh menunjukkan bahwa semua hipotesis dapat diterima model teoritis telah diuji dan uji asumsi klasi dan mendapatkan hasil yang baik pengujian dan juga menunjukkan hasil yang tidak menyimpang dari yang dihipotesiskan. Penelitian ini mengembangkan 2 hipotesis yang akan dibuktikan dengan data yang diperoleh. Hasil yang diperoleh dari uji masing-masing hipotesis adalah sebagai berikut :

H1 : Variabel Orientasi Kewirausahaan dan Inovasi Produk secara parsial (sendiri) berpengaruh positif dan signifikan terhadap kinerja keuangan UKM. 
Hasil penelitian menujukan bahwa variabel Orientasi Kewirausahaan, yaitu t-hitung > t-tabel atau 5,627 > 1,660 maka Ho ditolak dan hipotesis penelitian diterima, artinya Orientasi Kewirausahaan mempunyai pengaruh yang signifikan terhadap kinerja keuangan pada UKM Tenun Di Desa Pringgasela. Variabel Inovasi Produk, yaitu t-hitung > t-tabel atau 5,359 > 1,660 maka Ho ditolak dan hipotesis penelitian diterima, artinya Inovasi Produk mempunyai pengaruh yang signifikan terhadap Kinerja keuangan pada UKM Tenun Di Desa Pringgasela.

Pengaruh yang positif dan signifikan mencerminkan bahwa semakin baik Orientasi kewirausahaan yang dilakukan maka Kinerja keuangan UKM akan semakin baik pula, sedangkan sebaliknya apabila Orientasi Kewirausahaan semakin buruk maka akan mempengaruhi semakin buruknya Kinerja Keuangan.

Menumbuhkan dan mengembangkan semangat kewirausahaan perlu dilakukan kepada pelaku usaha untuk terus mengembangkan usaha yang telah lama dijalani, disamping maraknya persaingan usaha.

Kegiatan yang dilakukan dalam Orientasi kewirausahaan adalah bagaimana seorang pelaku usaha mampu mengambil resiko (sedang, ataupun tinggi) untuk keberlangsungan usaha yang dijalankan. Seorang pelaku usaha melakukan keproaktifan dan mampu membaca peluang-peluang yang bagus untuk usaha mereka, selain itu juga seorang pelaku usaha harus mampu menciptakan ide-ide yang cemerlang untuk membuat/mendesain produk yang mereka jual agar memiliki ciri khas tersendiri.

Hasil penelitian ini sejalan dengan penelitain yang dilakukan oleh Lekiastuti (2012), Djodjobo \& Tawas (2014), Suryanita (2016), Handayani (2015), Apriani (2012), dan Ikhsan (2015) yang menyatakan bahwa orientasi kewirausahaan dan inovasi produk secara parsial mempunyai pengaruh yang positif dan signifikan terhadap kinerja UKM.

\section{H2 : Variabel Orientasi Kewirausahaan dan Inovasi Produk secara} simultan (bersama-sama) berpengaruh positif dan signifikan terhadap kinerja keuangan UKM.

Hasil Pengujian hipotesis 2 dilakukan dengan membandingkan nilai $\mathrm{F}$ hitung dengan F-tabel. Dari hasil pengolahan data diketahui bahwa F hitung sebesar 
39,030 dan F-tabel pada derajat bebas regresi 2 dan derajat bebas residual 109 serta $\alpha 0,05$ adalah 3,09. F hitung $>\mathrm{F}$ tabel $(39,030>3,09)$, maka Ho ditolak, artinya ada pengaruh yang signifikan variabel Orientasi Kewirausahaan dan Inovasi Produk secara bersama-sama terhadap terhadap Kinerja Keuangan UKM Tenun Di Desa Pringgasela. Jadi dapat disimpulkan bahwa Orientasi Kewirausahaan dan Inovasi Produk secara bersama-sama terhadap Kinerja Keuangan UKM Tenun Di Desa Pringgasela. Selain membandingkan nilai $F$ hitung $n$ F tabel, dengan membandingkan nilai Sig dengan nilai $\alpha$ yaitu Sig $<\alpha 5 \%(0,000<0,05)$ maka Ho ditolak dan Ha diterima, artinya Orientasi Kewirusahaa dan Inovasi Produk secara bersama-sama (simultan) mempunyai pengaruh yang signifikan terhadap kinerja keuangan UKM Tenun di Desa Pringgasela.

Hasil penelitian ini sejalan dengan penelitain yang dilakukan oleh Lekiastuti (2012), Djodjobo \& Tawas (2014), Suryanita (2016), Handayani (2015), Apriani (2012), dan Ikhsan (2015), Murni (2015) yang menyatakan bahwa orientasi kewirausahaan dan inovasi produk secara simultan mempunyai pengaruh yang positif dan signifikan terhadap kinerja UKM

Pengaruh yang positif dan signifikan mencerminkan bahwa semakin baik Orientasi kewirausahaan dan inovasi produk yang dilakukan maka Kinerja keuangan UKM akan semakin baik pula, sedangkan sebaliknya apabila Orientasi kewirausahaan dan inovasi produk semakin buruk maka akan mempengaruhi semakin buruknya Kinerja Keuangan UKM.

Orientasi kewirausahaan berkaitan dengan pencarian peluang bagi para pelaku usaha, mencari peluang-peluang baru untuk terus mengembangkan usahanya. Semangat kewiraushaan harus tetap ada di dalam diri pelaku usaha, tanpa adanya semangat usaha akan sulit untuk menjalankan usaha. Selain semangat berwirausaha yang harus selalu ada dalam diri pelaku usaha hal yang terpenting juga harus melakukan pembaharuan produk (inovasi produk) agar mampu bersaing baik secara nasional maupun internasional.

\section{KESIMPULAN}

Penelitian ini mengembangkan hipotesis yang akan dibuktikan dengan data yang diperoleh. Hasil yang diperoleh dari uji masing-masing hipotesis adalah 
sebagai berikut :1). Koefisien Regresi Variabel Orientasi Kewirausahaan (X1) sebesar 0,454 menggambarkan bahwa Orientasi Kewirausahaan mempunyai pengaruh positif dan signifikan terhadap kinerja keuangan UKM Tenun di desa Pringgasela, artinya dengan semakin besarnya Orientasi Kewirausahaan maka Kinerja Keuangan UKM akan makin meningkat. 2). Koefisien Regresi Variabel Inovasi Produk (X2) sebesar 0,345 menggambarkan bahwa Inovasi Produk mempunyai pengaruh positif dan signifikan terhadap kinerja keuangan UKM Tenun Di Desa Pringgasela, artinya dengan semakin tingginya Inovasi Produk maka kinerja keuangan UKM Tenun Di Desa Pringgasela semakin meningkat.. 3). Hasil penelitian secara parsial (sendiri) dengan membandingkan nilai $t$ hitung dengan $t$ tabel menujukan bahwa variabel Orientasi Kewirausahaan, yaitu t-hitung > t-tabel atau 5,627 > 1,660 dengan membandingkan nilai sig yaitu sig $<\alpha 5 \%(0,000<$ 0,05), maka Ho ditolak dan hipotesis penelitian diterima, artinya Orientasi Kewirausahaan mempunyai pengaruh yang signifikan terhadap kinerja keuangan pada UKM Tenun Di Desa Pringgasela. Variabel Inovasi Produk, yaitu t-hitung > t-tabel atau 5,359 > 1,660 dengan membandingkan nilai sig yaitu sig $<\alpha 5 \%(0,000$ $<0,05)$, maka Ho ditolak dan hipotesis penelitian diterima, artinya Inovasi Produk mempunyai pengaruh yang signifikan terhadap Kinerja keuangan pada UKM Tenun Di Desa Pringgasela. 4). Hasil Pengujian hipotesis secara simultan (bersamasama) dilakukan dengan membandingkan nilai F hitung dengan F-tabel. Dari hasil pengolahan data diketahui bahwa $\mathrm{F}$ hitung sebesar 39,030 dan F-tabel pada derajat bebas regresi 2 dan derajat bebas residual 109 serta $\alpha$ 0,05 adalah 3,09. F hitung > F tabel $(39,030>3,09)$, maka Ho ditolak, artinya ada pengaruh yang signifikan variabel Orientasi Kewirausahaan dan Inovasi Produk secara bersamasama terhadap terhadap Kinerja Keuangan UKM Tenun Di Desa Pringgasela. Jadi dapat disimpulkan bahwa Orientasi Kewirausahaan dan Inovasi Produk secara bersama-sama terhadap Kinerja Keuangan UKM Tenun Di Desa Pringgasela. Selain membandingkan nilai F hitung n F tabel, dengan membandingkan nilai Sig dengan nilai $\alpha$ yaitu $\mathrm{Sig}<\alpha 5 \%(0,000<0,05)$ maka Ho ditolak dan Ha diterima, artinya Orientasi Kewirusahaa dan Inovasi Produk secara bersama-sama (simultan) 
mempunyai pengaruh yang signifikan terhadap kinerja keuangan UKM Tenun di Desa Pringgasela.

\section{DAFTAR RUJUKAN}

Apriani, Linda. 2015. Pengaruh Orientasi Kewirausahaan dan Inovasi peoduk terhadap keunggulan bersaing pada UKM Pakaian anak pagarsih Bandung. Tesis (dipublikasikan) Universitas Komputer Indonesia

Djodjobo Cynthia Vanessa dan Tawas Hendra N.. 2014. Pengaruh Orientasi Kewirausahaan, Inovasi Produk, dan Keunggulan Bersaing Terhadap Kinerja Pemasaran Usaha Nasi Kuning di Kota Manado. Jurnal EMBA, Vol.2 No.3, September. Hal. 1214-1224. ISSN 2303-1174

Ikhsan, Wahyu Muhammad. 2015. Pengaruh Orientasi Kewirausahaan dan Inovasi Produk terhadap keungulan bersaing pada sentra industri keramik kiara condong Bandung. Tesis Universitas Komputer Indonesia

Knight, Gary, 2000. Entrepreneurship and Marketing Strategy: The SME Under Globalization, Journal of International Marketing, Vol. 8, No.2, 2000, pp. 12 - 32

Littunen, Hannu, 2001. Entrepreneurship and Characteristies of The EntrepreneurshipPersonality. International Journal of Entrepreneurial Behaviour and Research. Vol.6.No.6, 2000. pp. 295 - 309

Lumpkin GT and Dess G.G, 1996, Clarifying the Entreprenuerial Orientation Construct and Linking it to Performance, Academy Management Review, Vol.21 No. 1, pp135-172

Lukiastuti,Fitri. 2012. Pengaruh Orientasi Wirausaha dan kapabisitas jejaring usaha terhadap peningkatan kinerja UKM dengan komitmen perilaku sebagai variabel intervening (Studi Empiris pada sentra UKM Batik di Sragen Jawa Tengah). Jurnal Organisasi dan Manajemen, Volume 8, Nomor 2, september 2012, 155-175

Murni, Tri. (2014). Pengaruh orientasi kewirausahaan terhadap kemampuan manajemen, strategi low cost, strategi difrensiasi, inovasi berkelanjutan dan kinerja usaha kecil \& menengah UKM (Studi pada UKM Batik Di Provinsi Jawa Timur). Jurnal Disertasi Fakultas Ilmu Administrasi universitas Brawijaya Malang.

Sugiono. (2012). Metode penelitian Kuantitatf Kualitatif dan $R \& D$. Bandung: Alfabeta

Suryanita, Andriani. 2006. Analisis Pengaruh Orientasi Kewirausahaan dan Kompetensi Pengetahuan Terhadap Kapabilitas Untuk Meningkatkan Kinerja Pemasaran. Tesis. Universitas Diponegoro, Semarang. 